دراسات في آثار الوطن العربي

\title{
The Archaeological Potentials of Ships
}

Dr. Emad Khalil ${ }^{*}$

\section{Introduction}

Boats and ships were the trains, planes, trucks and tanks of the past. They were extensively used and involved in various activities throughout the history of human kind. Direct evidence for boats has emerged as early as the $8^{\text {th }}$ millennium $\mathrm{BC}^{1}$, and since then, boats and ships have been the largest and most complex mobile structures produced ${ }^{2}$.

In order to discuss the archaeological potentials of boats and ships, it has to be clear that the ultimate objective of studying any archaeological source material is the insight they give into the people who produced and used them. In doing so, we hope for a better understanding of the development of human behaviour over periods of time and across regions and continents. Therefore, the value of archaeological source material is determined by the diversity and authenticity of information they yield. So, the more an object can tell us about people who produced and used it, the more valuable it becomes. Accordingly, this paper looks into the significance of boats and ships as valuable archaeological evidence,

* Dr. Emad Khalil, Lecturer in Maritime Archaeology, Department of Archaeology \& Graeco-Roman Studies, Faculty of Arts, Alexandria University. Email: emadkhalil@ hotmail.co.uk

${ }^{1}$ Ellmers D. 1996. The Beginnings of Boatbuilding in Central Europe. In B. Greenhill (ed.) The Earliest Ships, pp. 11-23. London: Conway Maritime Press McGrail, S. 2001. Boats of the World. Oxford: Oxford University Press

2 Muckelroy, K. 1978. Maritime Archaeology. Cambridge: Cambridge University Press, pp.3.

Murphy, L. 1983. Shipwrecks as Data Base for Human Behavioural Studies. In R. Gould (ed.) Shipwreck Anthropology, Albuquerque: University of New Mexico Press. pp. 65-89. 


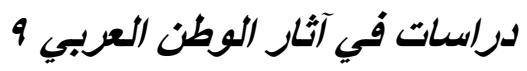

and the quality of knowledge they produce on life and activities of people who made and sailed them.

\section{The ships as an artefact}

There are two possible approaches to the study of boats and ships as material culture. They could be studied as objects in their own right, looking into their distinctive technical and functional attributes and materialistic features. Also, they could be viewed as cultural carriers, reflecting the environment, knowledge, material, traditions, organisation and beliefs of their parent societies ${ }^{3}$.

On the other hand, ships and boats have many characteristics, which distinguish them from most other types of artefacts and archaeological source material. Besides being complex, multifunctional, moving artefacts, what distinguishes them the most is the fact that they are an ideal representative of co-operation and teamwork in many of their characteristics.

Building and using boats might have started in its earlier stages as an individual operation, performed by a single person, but soon after, as ships became bigger and more complex, more people were involved in all phases of the ship 's working life, from construction to operation (figs.1, 2). Therefore, shipbuilding and sailing are considered social practices, which require co-operation and co-ordination between a number of men with different skills and capabilities. Accordingly, a ship is an ideal representation of co-operative social action, which utilising the most advanced and developed skills and knowledge of any society.

${ }^{3}$ Hasslöf, O. 1972. Main principles in the Technology of Ship-Building. In O. Hasslöf et al (eds.) Ships and Shipyards - Sailors and Fishermen, Copenhagen. pp. 27-72.

Murphy, L. op. cit.

Watson, P. 1983. Method and Theory in Shipwreck Archaeology. In R. Gould (ed.) Shipwreck Anthropolog,. Albuquerque: University of New Mexico Press. pp. 23-36 
In order for ships to perform and achieve their intended role as a major mean of transport, they varied in terms of shape and design according to different variables: the environment in which they were used, the missions they were to perform, and the availability of construction materials ${ }^{4}$; but they varied the most in terms of building techniques and traditions. Therefore, the study of ships provides us with an immense opportunity, not only to understand how they were built and operated in the past, but also to look into other aspects of the people who produced them, such as their ways of thinking in realising and solving problems. In other words, ships contain more varied information about their parent societies than many other categories of artefacts ${ }^{5}$.

\section{Ships and shipwrecks}

It is evident that the majority of ship-finds are from shipwreck sites. But there are other forms in which boats and ships enter the archaeological record, such as beached or abandoned crafts, or in connection with ritual practices ${ }^{6}$. However, with the number of boats and ships that have travelled over waterways for millennia, it is more likely to find ships underwater than on land. In the Mediterranean region alone there were 1189 shipwrecks dating

${ }^{4}$ Westerdahl, C. 1994. Maritime cultures and ship types: brief comments on the significance of maritime archaeology. The International Journal of Nautical Archaeology 23.4: 265-270.

${ }^{5}$ Maarleveld, T. J. 1995. Type or technique. Some thoughts on boat and ship finds as indicative of cultural tradition. International Journal of Nautical Archaeology 24.1:3-7.

${ }^{6}$ Kobylinski, Z. 1995. Ships, Society, Symbols and Archaeologists. In O. Crumlin-Pedersen \& B.M. Thye (eds.) The Ship as Symbol in Prehistoric and Medieval Scandinavia, Copenhagen: Danish National Museum. pp. 9-19.

Rieck, F. 1995. Ships and Boats in the Bog Finds of Scandinavia. In O. Crumlin-Pedersen \& B.M. Thye (eds.) The Ship as Symbol in Prehistoric and Medieval Scandinavia. Copenhagen: Danish National Museum. pp. 125-129. Adams, J. 2001. Ships and boats as archaeological source material. In D. Gibbins \& J. Adams (eds.) Shipwrecks. World Archaeology 32.3: 292-310. 
before $1500 \mathrm{AD}$ discovered until 1992, this number has significantly increased during the last decade $^{7}$. Therefore, shipwrecks have played a distinctive role in our knowledge of boats and ships and their archaeological values.

The coherence and integrity of shipwrecks are influenced by a number of factors, before, during or after the wrecking process. Generally speaking, shipwrecks are better preserved underwater than many ship-finds on land, due to the preservation qualities of the sub-aquatic environment (fig. 3). This is especially the case for wooden hulls deposited into the anaerobic sediments of the seabed ${ }^{8}$. But even if very little of the ship's hull survived, there are other indications and clues that could be drawn from the site on many aspects of the ship's construction method and working life.

Shipwrecks have the potential of being closed deposits with chronological harmony and contemporaneity of their various components; however, there is always the possibility of disturbance or contamination on site, whether due to environmental or human factors ${ }^{9}$. Therefore, within a wreck site, not every object is necessarily associated, even where the main wreck deposit is obviously coherent. Nevertheless, the ship's constructional elements are the most likely to be considered a closed find, or at least, less susceptible to contamination ${ }^{10}$, which makes the ship's hull one of the most reliable sources of information on a wreck site. Another quality that characterises shipwrecks as an archaeological resource is the absence of purpose, which results from the

${ }^{7}$ Parker, A. J. 1992. Ancient Shipwrecks of the Mediterranean \& the Roman Provinces: BAR International Series 580.

${ }^{8}$ Parker, A. op cit. pp. 5

${ }^{9}$ Muckelroy, K. op. cit.

Parker, A. J. 1981. Stratification and contamination in ancient Mediterranean shipwrecks. International Journal of Nautical Archaeology 10.4: 309-335.

Adams, J. op.cit

${ }^{10}$ Westerdahl, C. 1992. The maritime culture landscape. The International Journal of Nautical Archaeology 21.1: 5-14. 


\section{دراسات في آثار الوطن العربي 9}

accidental nature of the wrecking process. That makes the arrangement and survival of shipwrecks and their contents totally unintentional. Therefore, shipwreck sites provide us with a diversity of contemporary finds that were not intended for discard, which makes them more expressive and reflective of people's natural behaviour $^{11}$.

Accordingly, the following section will examine some key aspects of what ships, as a rich source of information; can tell us about people's environment, needs, technology, society and beliefs.

\section{I- Environment and material}

In all time periods, the choice of building material for local boats and ships depends mainly on the availability of such material locally $^{12}$, or the ability to obtain it from elsewhere. The ancient Egyptians used reed bundles to build boat-like rafts due to the abundance of the material along the Nile banks.

Likewise, the Inuits used hide and bones to build their umiaks, due to the availability of such materials in their local environment.

In other cases the material used in shipbuilding might not be locally available, which also gives an insight on the nature of the ships and the people's attitude towards them. The more significant and valuable a boat was to its builders, the more resources that could be devoted for its construction. For example, the funerary boat of Khufu was mainly constructed of imported Lebanese the Cedar, which indicates the significance of this boat and implies the royal monopoly of fine timber ${ }^{13}$.

Even at present, ethnographic evidence of traditional boats is

${ }^{11}$ Muckelroy, K. op. cit. pp. 215

${ }^{12}$ Cederlund, C.O. 1984. A systematic approach to the study of the remains of old boats and ships. In S. McGrail (ed.) Aspects of Maritime Archaeology and Ethnography. Greenwich: National Maritime Museum. pp. 173-209.

${ }^{13}$ Steffy, R. 1994. Wooden Shipbuilding and the Interpretation of Shipwrecks. Texas: Texas A\&M University Press. pp. 23-28.Ward, C. 2000. Sacred and Secular: Ancient Egyptian Ships and Boats. Philadelphia: University of Pennsylvania. pp. 20-22 


\section{دراسات في آثار الوطن العربي 9}

considered a valuable source of information on people and their environment in many parts of the world. During a field project conducted by the Centre for Maritime Archaeology at the University of Southampton for recording an ethnographic collection of boats; it was noticed in one of the traditional fishing boats from Oman, that several planks of the fore and after decks had a number of wooden pegs in them, operating as plugs (fig. 4). Many of those planks had been reused, probably from another earlier boat, and the pegs were used to plug holes remaining from the previous use of those planks. This certainly gives a clear insight on the kind of environment and conditions this boat was built in. It was probably built in an environment lacking the natural or economic resources to obtain fine boat timber.

\section{II- Needs and activities}

The ship is a product urged by specific needs in the society. Hence, a ship's construction and operation are supposed to fulfil such needs. Therefore, in most cases, a ship's design will reflect its primary purpose and use, whether it was a merchantman, a warship, a fishing boat, etc., which represents a direct response to the society's maritime requirements, i.e. trade, warfare, etc. ${ }^{14}$. It is the society's need for a certain type of water transport that stimulates and influences the construction of a ship and its characteristic features, and, as that need develops or changes, it is directly reflected on the design and features of the produced vessels.

On shipwrecks of trade vessels we can relate the development of the design and capacity of the ship to the type and size of cargo it carried $^{15}$, while the study of cargo could give valuable insights on the ship's activities and trade routes (fig. 5).

${ }^{14}$ Lenihan, D. J. 1983. Rethinking Shipwreck Archaeology. In R. Gould (ed.) Shipwreck Anthropology, pp. 37-64. Albuquerque: University of New Mexico Press. pp. 53.

${ }^{15}$ Steffy, R. op.cit. pp. 62-65. 


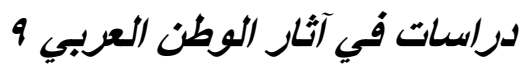

It is evident that amphorae have been the predominant containers of goods in the ancient world. The study of ancient shipwrecks, especially in the Mediterranean, resulted in a significant development in the study of amphorae, their typology, distribution and contents, and therefore in a better understanding of ancient trade and economy ${ }^{16}$.

For example, the study of ancient shipwrecks in the Mediterranean conducted in by Anthony Parker ${ }^{17}$ revealed that the majority of discovered wrecks, which date from the Bronze Age until the $14^{\text {th }}$ century, actually date to the period from $150 \mathrm{BC}$ to $150 \mathrm{AD}$ (fig. 6). So, it seems that during these 300 years the Mediterranean must have seen its heaviest maritime commercial activity in ancient history. This is just an example of the quality of information we can obtain from the study of ships.

On the other hand, shipwrecks are a wealthy source of information on trade routes and transport systems in different regions and periods. The cargo items found in the $14^{\text {th }}$ century BC shipwreck of Uluburun - Turkey, were mostly of valuable raw materials, such as tin, copper, glass and ivory, which could be an indication for a directional trade route between specific ports in the eastern Mediterranean ${ }^{18}$. However, one should be cautious of such interpretation based on the assumption that places of origin of goods found on a shipwreck indicate its trade routes, as transshipment, inter-ports and return cargoes, could all be misleading factors ${ }^{19}$.

${ }^{16}$ Peacock, D. \& Williams, D. 1991. Amphorae and the Roman Economy: An Introductory Guide. LongmanSciallano, M. \& Sibella, P. 1991. Amphores, comment les identifier? Édisud, Aix en Provence.

${ }^{17}$ Parker, A. 1992.

18 Pulak, C. 1998. The Uluburun shipwreck: and overview. International Journal of Nautical Archaeology 27.3: 188-224. Bass, G. (ed.) 2005. Beneath the Seven Seas. London: Thames and Hudson. pp. 34-47.

${ }^{19}$ Parker, A. J. 1995. Maritime cultures and wreck assemblages in the GrecoRoman World. International Journal of Nautical Archaeology 24.2: 87-95. 
War is the other side of the coin which could be realised by from the study of warships and their development. Warships' design, construction technique and contents of armament and associated material directly reflect the prevailing military technology and naval strategies of a certain region in a certain period ${ }^{20}$.

In the Greco-Roman times, the ship itself was utilized as a weapon (fig. 7), so that the ramming technique was the standard tactic in sea battles in the ancient Mediterranean. However, by the Medieval Period, the concept of sea battles have changed, so warships were used as floating battlefields for fighting to take place on board as if it was on land (fig. 8). Soon, the introduction of naval artillery changed once more the concept of sea battle.

Accordingly, the study of ships, their features and their contents, contributes significantly to the reconstruction and interpretation of the contemporary economic and political trends of their parent societies $^{21}$.

\section{III- Technology and shipbuilding traditions}

Maarleveld $^{22}$ eloquently describes ships and boats as being 'technological echoes of their parent cultures'. This statement is undoubtedly true, since shipbuilding technology is an evident reflection of the technical development of any society. It utilises the available material, labour and knowledge to fulfil the society's need

${ }^{20}$ Muckelroy, K. op. cit. pp. 219-221

Lenihan, D. op. cit. pp. 59-60.

Gardiner, R. \& Morrison, J. (eds.) 2000. The Age of the Galley: Mediterranean Oared Vessels since pre-Classical Times. London: Conway Maritime Press.

${ }^{21}$ Murphy, L. 1983. Shipwrecks as Data Base for Human Behavioural Studies.

In R. Gould (ed.) Shipwreck Anthropology, pp. 65-89. Albuquerque: University of New Mexico Press. pp. 83-86.

Muckelroy, K. 1980. Techniques and approaches. In K. Muckelroy (ed.) Archaeology Under Water. New York. pp. 12-31

${ }^{22}$ Maarleveld, T. J. 1995. Type or technique. Some thoughts on boat and ship finds as indicative of cultural tradition. International Journal of Nautical Archaeology 24.1. pp. 3. 


\section{دراسات في آثار الوطن العربي 9}

for water transport. It is an expression of how people conceive certain problems and their solutions. However, in applying technology to shipbuilding, people operate within the parameters of their shipbuilding tradition; in fact, tradition is the way people conceive technology should be applied. It is the way they believe things should be done.

Each boat and ship could be looked at as an individual case that might bear certain features and characteristics, which are not evident in another vessel; however, there are general trends in ship construction, which can be referred to as shipbuilding traditions. As defined by McGrail ${ }^{23}$, shipbuilding tradition is 'the perceived style of building, generally used in a certain region during a given time range', nevertheless, shipbuilding tradition is considered a dynamic process.

Although, it is not a simple matter to make changes in a complicated prevailing practice such as shipbuilding, however, innovation and the desire for improvement penetrate the process of transmitting tradition, and lead to very gradual changes over long periods of time ${ }^{24}$.

The universal problem that faced shipbuilders throughout history was making their plank seams watertight. Different technical solutions for this problem were adopted in different regions and periods. Mortise-and-tenon joined planks was the predominant technique in ancient Mediterranean ships, clinker built planks in European ships and stitched planks in Arab and Indian ships etc. (fig. 9), these all are different ways shipbuilders conceived as solutions for their problem ${ }^{25}$. Even in the same society we can see

${ }^{23}$ McGrail, S. 1995. Romano-Celtic boats and ships: characteristic features. International Journal of Nautical Archaeology 24.2. pp. 139.

${ }^{24}$ Crumlin-Pedersen, O. 1972. Skin or wood? A study of the Origin of the Scandinavian Plank-Boat, In O. Hasslöf et al (eds.) Ships and Shipyards Sailors and Fishermen. Copenhagen. pp. 208-234.

${ }^{25}$ Hocker, F. \& Ward, C. 2004. The Philosophy of Shipbuilding. College Station: Texas A\&M University Press. pp. 25-63 
different techniques adopted in boat and shipbuilding. For example figures 1 and 10 show boat building scenes depicted in tombs of the 5th Dynasty from Saqqara, however, the technique adopted in each of them is different from the other, as a result of economic, social and environmental factors.

The study of the construction technique of some of the oldest known boats $^{26}$ : the Khufu boat in Egypt (c. 2500 BC), the Ferriby 1 boat in Britain (c. $1300 \mathrm{BC}$ ), and the Uluburun wreck in Turkey $\left(14^{\text {th }}\right.$ century BC) revealed that they were all built shell-first ${ }^{27}$. This fact suggests that the earliest planked boats worldwide were probably built shell-first. Although there were several different constructional details and fastening methods between those boats, and they were also used in different environments and for different proposes, however, the fact that they were all built-shell first, indicates that their builders had similar ideas about how things should be done.

Also by looking at successive shipbuilding techniques in a certain region we can shed light upon the process of change and development in such techniques, aiming to understand the various factors that stimulated such changes. For example in the Mediterranean, the shell-fist building technique with mortise-andtenon fastenings was predominant since the first evidence of boat building until the Byzantine period. So, the $14^{\text {th }}$ century B.C Uluburun ship was built shell-first with mortise-and-tenon joints. Twenty centuries later the $7^{\text {th }}$ century Yassi Ada ship was partially built in shell-first to the turn of the bilge, then frames were fitted and the rest of the planks nailed to them. Four hundred years later the $11^{\text {th }}$ century Serçe Limani ship was built completely frame-

${ }^{26}$ Bass, G. op. cit. pp. 34-47

${ }^{27}$ In the shell-fist construction technique, the planking of the ship is fastened together first to form the ship's hull, then the internal frames 'ribs' are inserted and fastened to the planking from the inside of the hull. 
first $^{28} 29$. From this evidence it is noticeable that shipwrights of the Mediterranean took much longer time to initiate the conversion from the shell-first technique to the fame- first, while it took them much less time to realise the advantages of the new method and therefore to adopt it for later centuries. It is obvious that such a change occurred over centuries of development, experimentation and innovation. The new technique would allow shipbuilders to build bigger and easier to maintain ships from a poorer quality of timber and by less-skilled labour (McGrail 1996). But whether or not these were their reason for that conversion; the answer has to consider numerous social, economic and technological factors, which were the medium for such a change. Shipbuilding traditions, throughout time, cannot be explained based on their materialistic evidence only; they have to be viewed in the light of their social context.

It was the study of boats and ships that led to the discovery of the various building traditions and techniques, and enabled us to interpret the differences and similarities between such traditions and try to trace their development in different regions and over periods of time.

\section{IV- Society and organisation}

When we speak of ships as representatives of their parent societies, one has to be aware that there are two social assemblages involved and represented by the ship. The first is the one that produced the ship, i.e. the contemporary society with all its technological, economic and social aspects involved in the production of the ship.

${ }^{28}$ In the frame-first construction technique, the internal frames 'ribs' of the ships are first fastened to the keel forming the skeleton of the ship, and then the outer planks are fastened to the frames from the outside. This is the method currently used in wooden shipbuilding.

${ }^{29}$ Steffy, R. op. cit. pp. 79-91

Bass, G. op. cit. pp. 106-117

Pulak, C. op. cit.

Hocker, F. \& Ward, C. op.cit. 


\section{دراسات في آثار الوطن العربي 9}

The second is the shipboard society of sailors, mariners, and merchants involved in the ship's operation. Those could be represented in the archaeological record by their personal belongings and their accommodation and working areas on board. As mentioned earlier, shipbuilding is a complex social activity. Several people might contribute their efforts and expertise in various crafts and professions in order to produce a ship ${ }^{30}$. Therefore, the ship does not reflect the skilfulness and dexterity of one person, like many other artefacts, but it expresses the qualifications and knowledge of a group of craftsmen and artisans, which makes the ship more reliable in terms of expressing the capabilities of a wider section of the community.

The same thing could be said about operating a ship, which is also a co-operative social operation, where human behaviour is a major element. It is even suggested that the most important single cause of ship loss is human error, which makes the quality of the crew, the most important single variable in determining the fate of a ship ${ }^{31}$.

A major characteristic feature in a shipboard community is the idea of living in a confined space for a considerable duration of time, sharing risks and performing different roles and activities to achieve common goals: successful operation of ship, completion of the mission and survival at sea ${ }^{32}$. For example, a $5^{\text {th }}$ century BC

Trireme had about 200 men onboard ${ }^{33}$, while an $18^{\text {th }}$ century warships would have carried more than 800 men. In both cases, these men had to work together to succeed. However, a shipboard society is considered a temporary one; its existence and persistence are tied to the accomplishment of the mission; afterwards, its members could get engaged in other social practices or

${ }^{30}$ Adams, J. op. cit.

${ }^{31}$ Muckelroy, K. 1978. pp. 232, 1980:28

${ }^{32}$ Murphy, L. op. cit. pp. 67

${ }^{33}$ Morrison, J. 2000. The Trireme. In R. Gardiner \&, J. Morrison (eds.), The Age of the Galley: Mediterranean Oared Vessels since pre-Classical Times. London: Conway Maritime Press , pp 49-65. 
occupations $^{34}$. Also a shipboard society is considered dynamic, as there are often changes in personnel taking part in it. With each change, a new element is introduced which might have direct impact on the ship's performance or fate, for example, replacing a competent captain with an impetuous one, or vice versa.

The form and organisation of a shipboard society will vary according to the ship's type, size and activity. It is often more distinct in bigger and later ships, originating from more complex societies. The social structure on board of a $16^{\text {th }}$ century warship such as the Mary Rose, with a significant distinction between sailors, officers and soldiers is evidently different from the community on board of a $7^{\text {th }}$ century merchant ship with 4 or $5 \mathrm{crew}$ members, such as the Yassi $\mathrm{Ada}^{35}$.

However, in all cases, the ship's remains will bear some evidence on the nature and stratification of its onboard society. This social stratification is often represented archaeologically by differences among artefact assemblage, but it could also be indicated in the ship's construction in term of dividing the living space between different groups of crewmembers. With limited space available on board ships, the space allocated for a certain class or group or even a single person onboard, reflects their importance on board ${ }^{36}$. Therefore, the study of ships can produce immense information about the life of people who were onboard.

For example, through the study of the ship remains and the distribution of artefacts of the 7th century shipwreck at Yassi Ada, it was possible to get a clear idea about the size and form of this

${ }^{34}$ Henningsen, H. 1972. The Life of the Sailors Afloat and Ashore. In O. Hasslöf et al (eds.) Ships and Shipyards - Sailors and Fishermen, pp. 123150. Copenhagen.

${ }^{35}$ Bass, G. op. cit. pp. 92-97 Adams, J. op. cit.

${ }^{36}$ Lenihan, D. op.cit.

Colin, D. \& Murphy, L. 1998. Shipboard Society. In J.P. Delgado (ed.) Encyclopedia of Underwater and Maritime Archaeology,Yale University Press. pp. 372-375. 


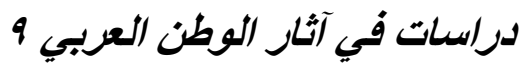

shipboard society, as well as its daily life activities. It was also noticeable that the artefacts associated with the crew, i.e. the personal items, were concentrated in the stern area, where a welldesigned galley was situated. It accommodated remarkably extensive cooking and serving facilities for a vessel of only about 40 tons burden. This information reflected the social and economic significance of the independent ship owners of the $7^{\text {th }}$ century, which formed an important and influential class in the Byzantine society, where they played the role of ship owners, captains and merchantmen $^{37}$.

Not only the personal items and the ship's design that give indication on the shipboard society, but also the remains of foodstuff and other organic remains, which have been found and studied in many shipwrecks from different time periods. It has yielded significant information on the crew and passengers' diet and health condition. It was also an indication on what provisions were available in the ship's port of origin or at re-provisioning stops on the way to its destination ${ }^{38}$.

\section{V- Rituals and beliefs}

Ships have achieved a very high symbolic value in all cultures. They have been given different religious and mythological roles in various communities throughout time ${ }^{39}$. Therefore, many boat finds in different regions were the result of ritual practices. They took the form of boat burials, boat graves, elements of burial furniture,

${ }^{37}$ Van Doorninck, F. 1972. Byzantium, mistress of the sea 330-641. In G. F. Bass (ed.) A History of Seafaring Based on Underwater Archaeology, New York: Walker and Company, pp. 134-158.

Muckelroy, K. 1978, pp. 222.

Bass, G. op. cit. 92-97.

${ }^{38}$ Haldane, C. 1993. Direct evidence for organic cargoes in the Late Bronze Age. World Archaeology, 24, pp. 348-60.

Pulak, C. op. cit.

39 Cederlund, C.O. 1995. Marie archaeology in society and science. International Journal of Nautical Archaeology 24.1: 9-13. 


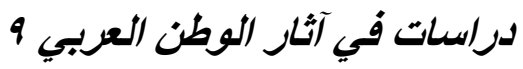

votive offerings, or boats deliberately deposited in bogs in connection with religious practices or as a form of sacrifice ${ }^{40}$. The fact that the oldest plank boats known so far, the Abydos boats, are from boat graves, where 12 boats were found buried in the desert more than 11 kilometres from the Nile, this strongly suggests that boats have acquired a symbolic characteristic since the early stages of their use ${ }^{41}$.

In ancient Egypt boats were used for transporting newly mummified bodies across the Nile to their tombs. Also, boat models were included in burials and funerary monuments. In ancient Egyptian mythology, boats were considered the only way to reach the gods, while the Sun god Ra used boats for traversing the sky by day and by night ${ }^{42}$. There is also an abundance of evidence on the symbolic value of boats and ships in prehistoric and early medieval Northern Europe societies, where they have been involved in several forms of ritual practices ${ }^{43}$.

Another aspect of the ritual value of boats is the fact that many religious practices were taking place on board of boats and ships probably since the very early stages of human beliefs ${ }^{44}$. Iconographic and archaeological evidences have shown that altars for religious ceremonies were carried on ships since the $2^{\text {nd }}$ century $\mathrm{BC}$ (fig. 11). Also in ancient times it was a common practice that a ship would carry a figurine or a statuette or even the name of its

${ }^{40}$ Kobyliński, Z. op.cit.

Rieck, F. op. cit.

Adams, J. op. cit

${ }^{41}$ Ward, C. op. cit. pp.39-41

${ }^{42}$ Ward, C. ibid. pp. 1-12

${ }^{43}$ Westerdahl, C. 1994. op. cit.

44 Kapitän, G. 1985. Archaeological Evidence for Rituals and Customs on Ancient Ships. In Harry Tzalas (ed.) Tropis I, $1^{\text {st }}$ International Symposium on Ship Construction in Antiquity. Piraeus., pp. 147-162

Casson, L. 1995. Ships and Seamanship in the Ancient World. Baltimore: The John Hopkins University Press. pp. 181-2. 


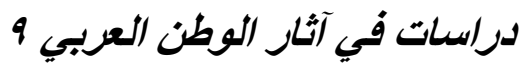

protective deity. For example, much evidence indicate that a common name for merchant and warships in the ancient Mediterranean was "Isis", as the Egyptian goddess was considered the protective deity of the sailors and seafarers ${ }^{45}$.

Nevertheless, such symbolic value of boats still persists in some societies. For example, the outboard surface of the stem cap of the Indian fishing boats known as 'the Patia' is usually carved to represent the face of the goddess Kali, the protective goddess for the boat and $\mathrm{crew}^{46}$; while, religious statements still cover the bodies of traditional fishing boats in local harbours all over Egypt (figs. $12 \& 13$ ).

Such features cannot be functionally or practically justified. They have to be looked at in terms of the society's ideology and beliefs. Therefore, ships and boats are an immense source of knowledge on the beliefs and religious practices of different societies.

\section{Conclusion}

Ships have developed all over the world in different ways and at different speeds. Their development has been conditioned by the geography of the local waters, climate, purpose for which the boat was needed, availability of materials for their construction, tradition of craftsmanship which grew up among the boat builders and the general state and nature of the culture of the people building them ${ }^{47}$

The previously mentioned parameters are all very much linked and correlated; they all form the milieu in which the ship builders and users operate. Our ultimate goal is to know bout those people; their

${ }^{45}$ Casson, L. 1995. Ships and Seamanship in the Ancient World. Baltimore: The John Hopkins University Press, pp. 186, 358.

46 Blue, L. et al 1997. The Patia Fishing Boat of Orissa: A Case Study in Ethnoarchaeology. South Asian Studies 13, pp. 198-207.

47 Greenhill, B. 1995. The Archaeology of Boats and Ships. Maryland: Naval Institute Press, pp. 20. 


\section{دراسات في آثار الوطن العربي}

life, their behaviour and their way of thinking. Ships, in this case, are our access to such knowledge. Through the study of several individual ships, on chronological, regional, and typological bases, we try to figure out general principles that governed humans' behaviour and their endeavour towards fulfilling their increasing and developing needs and solving their problems. Ships and boats are wealthy sources of archaeological material, with their potential insights into ancient societies. However, we should also combine the information acquired from them, with all other possible sources of information: textual, documentary, iconographic, and ethnographic sources, in order to achieve a clearer view of man's relationship to his maritime environment.Ships and boats are invaluable tools, with which we try to understand, not only how, when and where people lived but also, why they lived the way they did.

\section{References Cited:}

Adams, J. 2001. Ships and boats as archaeological source material. In D. Gibbins \& J. Adams (eds.) Shipwrecks. World Archaeology 32.3: 292-310.

Bass, G. (ed.) 2005. Beneath the Seven Seas. London: Thames and Hudson.

Bass, G. 1996. Shipwrecks in the Bodrum Museum of Underwater Archaeology. Bodrum: Museum of Underwater Archaeology.

Blue, L., Kentley, E., McGrail, S. \& Mishra, U. 1997. The Patia Fishing Boat of Orissa: A Case Study in Ethnoarchaeology. South Asian Studies 13: 198-207.

Casson, L. 1995. Ships and Seamanship in the Ancient World. Baltimore: The John Hopkins University Press.

Casson, L. 1996. Ships and Seafaring in Ancient Times. University of Texas Press.

Cederlund, C.O. 1984. A systematic approach to the study of the remains of old boats and ships. In S. McGrail (ed.) Aspects of Maritime Archaeology and Ethnography, pp. 173-209. 
Greenwich: National Maritime Museum.

Cederlund, C.O. 1995. Marie archaeology in society and science. International Journal of Nautical Archaeology 24.1: 9-13.

Colin, D. \& Murphy, L. 1998. Shipboard Society. In J.P. Delgado (ed.) Encyclopedia of Underwater and Maritime Archaeology, pp. 372-375: Yale University Press.

Crumlin-Pedersen, O. 1972. Skin or wood? A study of the Origin of the Scandinavian Plank-Boat, In O. Hasslöf et al (eds.) Ships and Shipyards - Sailors and Fishermen, pp. 208-234. Copenhagen.

Ellmers D. 1996. The Beginnings of Boatbuilding in Central Europe. In B. Greenhill (ed.) The Earliest Ships, pp. 11-23. London: Conway Maritime Press.

Gardiner, R. \& Morrison, J. (eds.) 2000. The Age of the Galley: Mediterranean Oared Vessels since pre-Classical Times. London: Conway Maritime Press.

Gould, R. 1983. Looking Below the Surface. In R. Gould (ed.) Shipwreck Anthropology, pp. 3-22. Albuquerque: University of New Mexico Press.

Greenhill, B. 1995. The Archaeology of Boats and Ships. Maryland: Naval Institute Press.

Haldane, C. 1993. Direct evidence for organic cargoes in the Late Bronze Age. World Archaeology, 24: 348-60.

Hasslöf, O. 1972. Main principles in the Technology of ShipBuilding. In O. Hasslöf et al (eds.) Ships and Shipyards Sailors and Fishermen, pp. 27-72 Copenhagen.

Henningsen, H. 1972. The Life of the Sailors Afloat and Ashore. In O. Hasslöf et al (eds.) Ships and Shipyards - Sailors and Fishermen, pp. 123-150. Copenhagen.

Hocker, F. \& Ward, C. 2004. The Philosophy of Shipbuilding. College Station: Texas A\&M University Press.

Kapitän, G. 1985. Archaeological Evidence for Rituals and Customs on Ancient Ships. In Harry Tzalas (ed.) Tropis I, $1^{\text {st }}$ 
International Symposium on Ship Construction in Antiquity, pp. 147-162. Piraeus

Kobylinski, Z. 1995. Ships, Society, Symbols and Archaeologists.

In O. Crumlin-Pedersen \& B.M. Thye (eds.) The Ship as

Symbol in Prehistoric and Medieval Scandinavia, pp. 9-19.

Copenhagen: Danish National Museum.

Lenihan, D. J. 1983. Rethinking Shipwreck Archaeology. In R. Gould (ed.) Shipwreck Anthropology, pp. 37-64. Albuquerque: University of New Mexico Press.

Maarleveld, T. J. 1995. Type or technique. Some thoughts on boat and ship finds as indicative of cultural tradition. International Journal of Nautical Archaeology 24.1:3-7.

Morrison, J. 2000. The Trireme. In R. Gardiner \&, J. Morrison (eds.), The Age of the Galley: Mediterranean Oared Vessels since pre-Classical Times, pp 49-65. London: Conway Maritime Press.

McGrail, S. 1995. Romano-Celtic boats and ships: characteristic features. International Journal of Nautical Archaeology 24.2: 139-145.

McGrail, S. 1996. The Ship: Carrier of Goods, People and Ideas. In E. E. Rice (ed.) The Sea and History, pp. 67-96. Gloucestershire: Sutton Publishing Ltd.

McGrail, S. 2001. Boats of the World. Oxford: Oxford University Press.

Muckelroy, K. 1978. Maritime Archaeology. Cambridge: Cambridge University Press.

Muckelroy, K. 1980. Techniques and approaches. In K. Muckelroy (ed.) Archaeology Under Water, pp. 12-31. New York.

Murphy, L. 1983. Shipwrecks as Data Base for Human Behavioural Studies. In R. Gould (ed.) Shipwreck Anthropology, pp. 6589. Albuquerque: University of New Mexico Press.

Parker, A. J. 1981. Stratification and contamination in ancient Mediterranean shipwrecks. International Journal of Nautical 
Archaeology 10.4: 309-335.

Parker, A. J. 1992. Ancient Shipwrecks of the Mediterranean \& the Roman Provinces: BAR International Series 580.

Parker, A. J. 1995. Maritime cultures and wreck assemblages in the Greco-Roman World. International Journal of Nautical Archaeology 24.2: 87-95.

Peacock, D. \& Williams, D. 1991. Amphorae and the Roman Economy: An Introductory Guide. Longman.

Pulak, C. 1998. The Uluburun shipwreck: and overview. International Journal of Nautical Archaeology 27.3: 188-224.

Rieck, F. 1995. Ships and Boats in the Bog Finds of Scandinavia. In O. Crumlin-Pedersen \& B.M. Thye (eds.) The Ship as Symbol in Prehistoric and Medieval Scandinavia, pp. 125129. Copenhagen: Danish National Museum.

Sciallano, M. \& Sibella, P. 1991. Amphores, comment les identifier? Édisud, Aix en Provence.

Steffy, R. 1994. Wooden Shipbuilding and the Interpretation of Shipwrecks. Texas: Texas A\&M University Press.

Van Doorninck, F. 1972. Byzantium, mistress of the sea 330-641. In G. F. Bass (ed.) A History of Seafaring Based on Underwater Archaeology, pp. 134-158. New York: Walker and Company.

Ward, C. 2000. Sacred and Secular: Ancient Egyptian Ships and Boats. Philadelphia: University of Pennsylvania.

Watson, P. 1983. Method and Theory in Shipwreck Archaeology. In R. Gould (ed.) Shipwreck Anthropology, pp. 23-36. Albuquerque: University of New Mexico Press.

Westerdahl, C. 1992. The maritime culture landscape. The International Journal of Nautical Archaeology 21.1: 5-14.

Westerdahl, C. 1994. Maritime cultures and ship types: brief comments on the significance of maritime archaeology. The International Journal of Nautical Archaeology 23.4: 265-270 


\section{دراسات في آثار الوطن العربي 9}

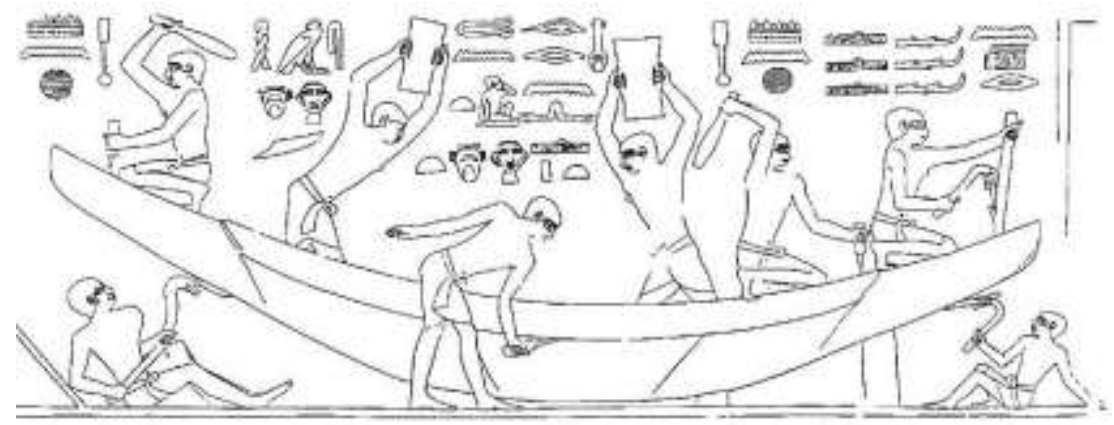

Figure 1. Boat building as a cooperative action. A plank boat under construction using mortise and tenon technique. From the Mastaba of Ti at Saqqara - Fifth-Dynasty. (After Steffy 1994:

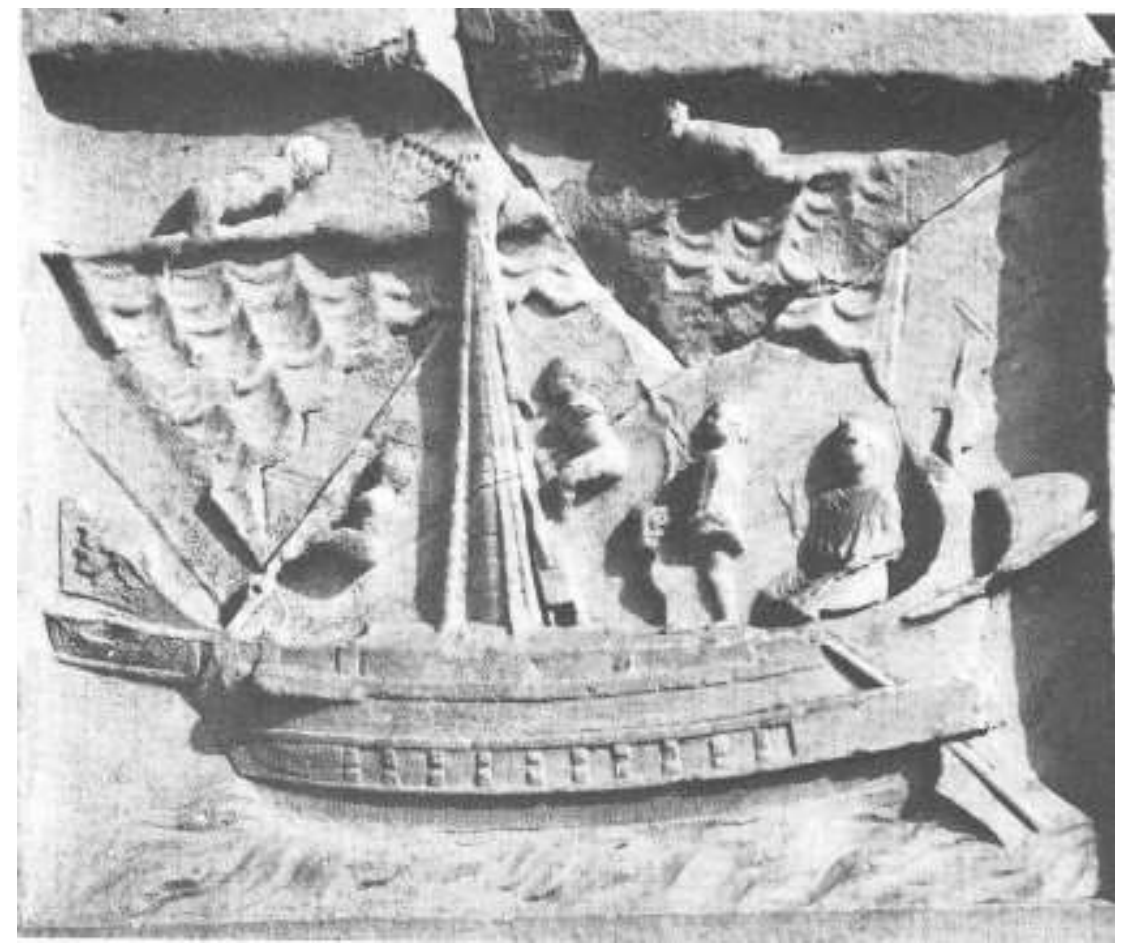

Figure 2. Ship operation as a co-operative practice. A Roman merchant ship entering port. From a tombstone from Pompeii, AD 50. (After Casson 1996: 114) 


\section{دراسات في آثار الوطن العربي 9}

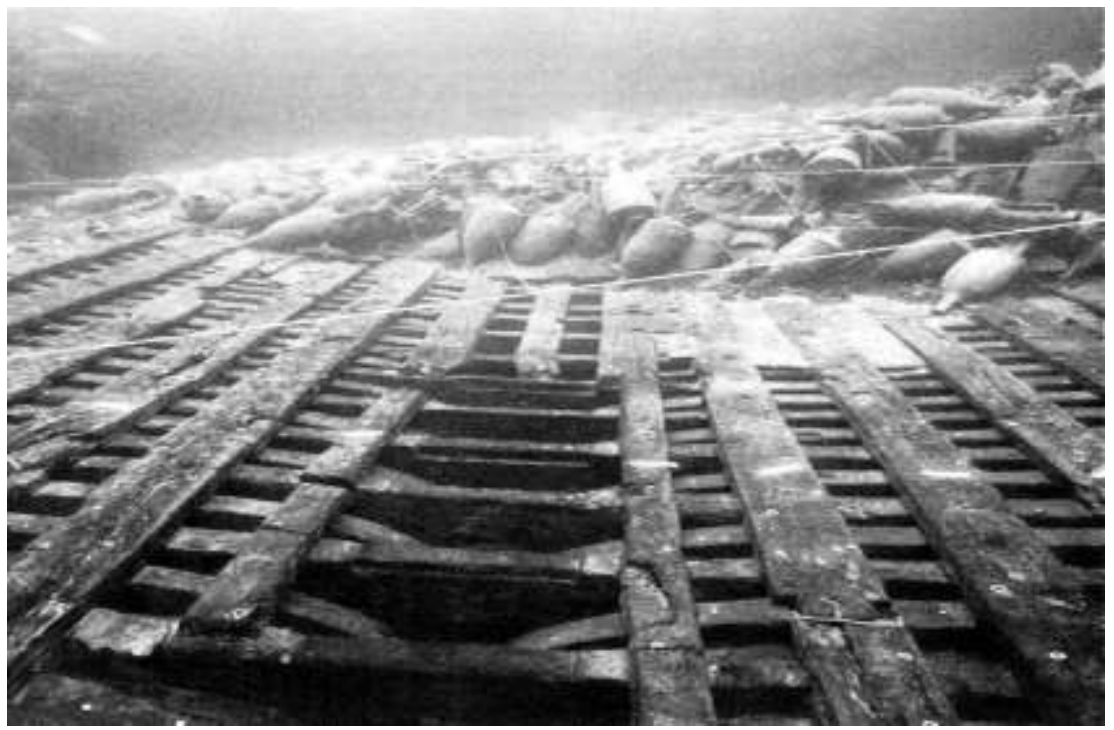

Figure 3. A well-preserved wooden hull of the 2nd century B.C. wreck of La Madrague de Giens. (After Casson 1996: 105)

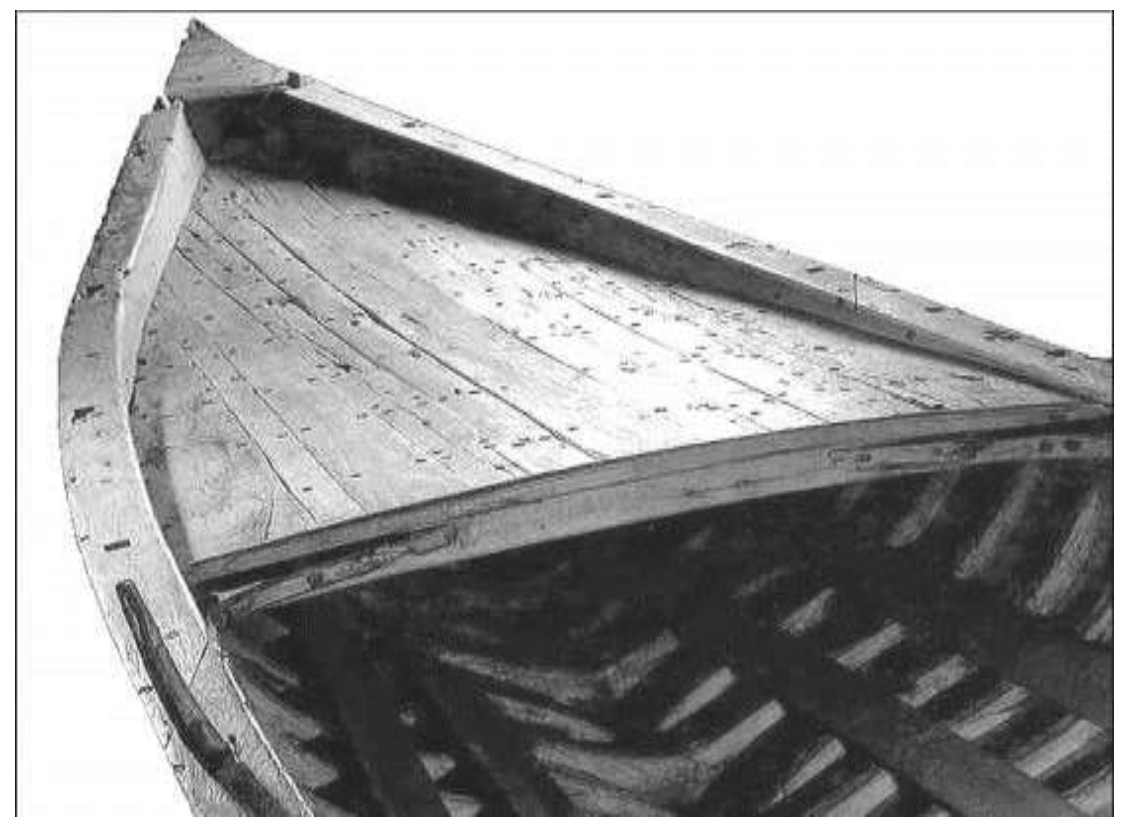

Figure 4: The fore deck of the 'Umla', a fishing boat from Oman, with the wooden pegs operating as plugs. (Modified after Greenhill 1995) 


\section{دراسات في آثار الوطن العربي 9}

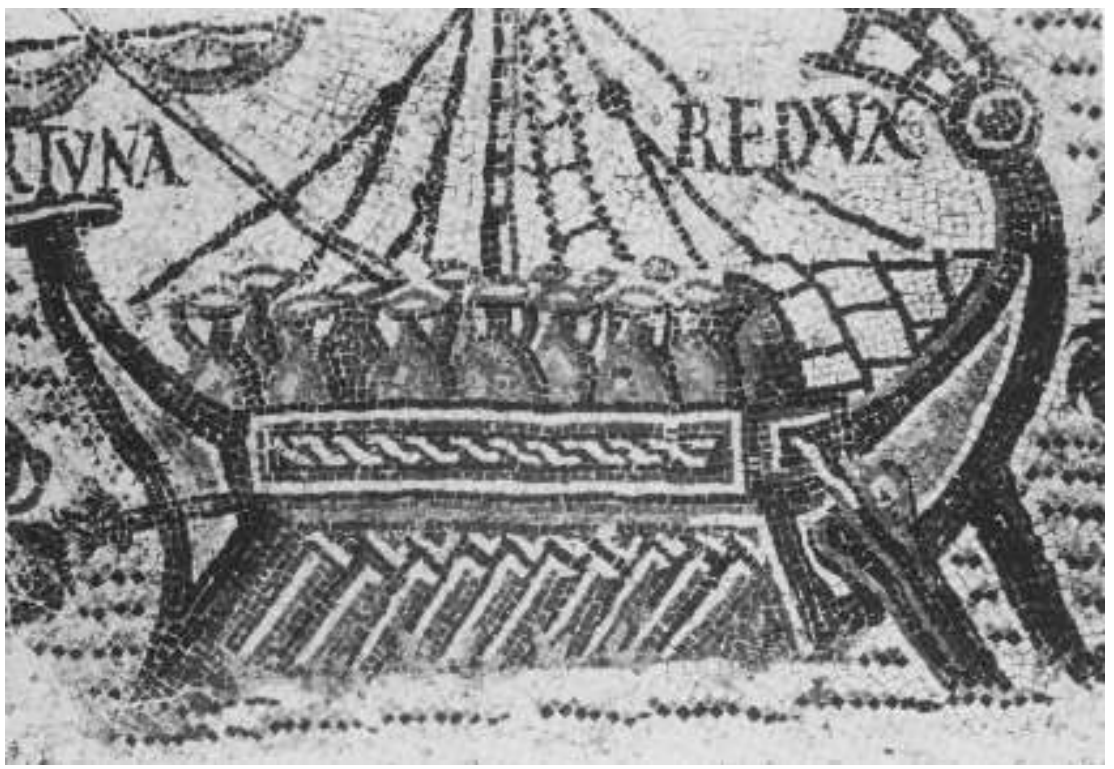

Figure 5: A merchant galley loaded with amphorae. Mosaic from Algeria $-2^{\text {nd }}-3^{\text {rd }}$ century AD. (After Casson 1996: 125)

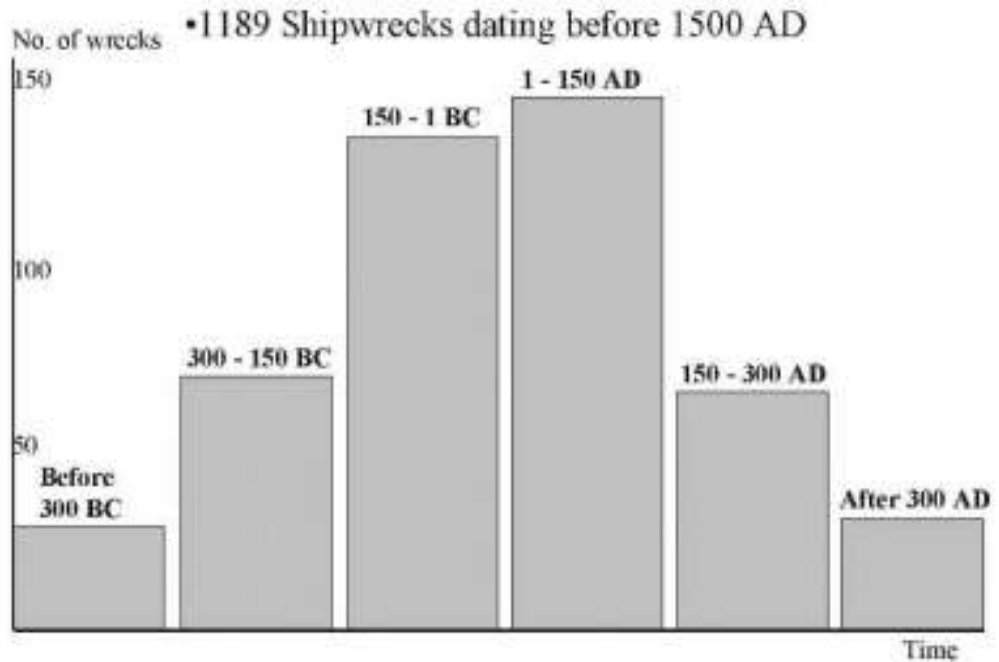

Figure 6: The majority of ancient shipwrecks discovered in the Mediterranean date between $150 \mathrm{BC}-150$ $\mathrm{AD}$; an indication on intensive maritime activity during that period (Parker 1992). 


\section{دراسات في آثار الوطن العربي 9}

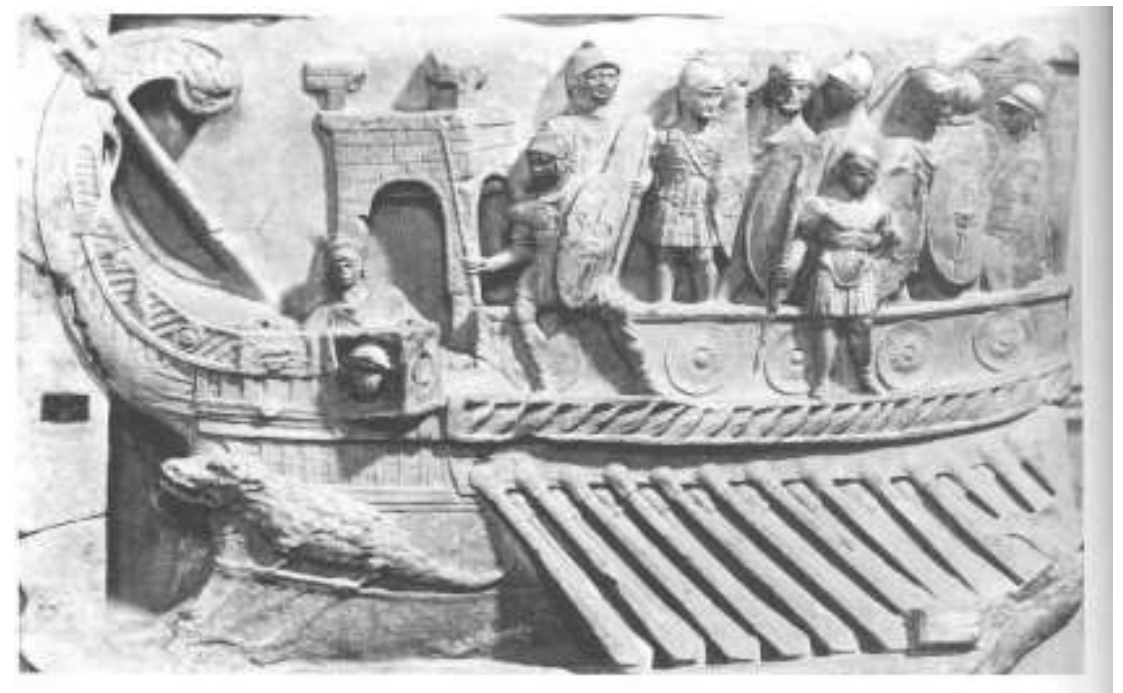

Figure 7: A Roman warship of the $1^{\text {st }}$ century BC used its ram as the main weapon for sea battle. (After Casson 1996: 92).

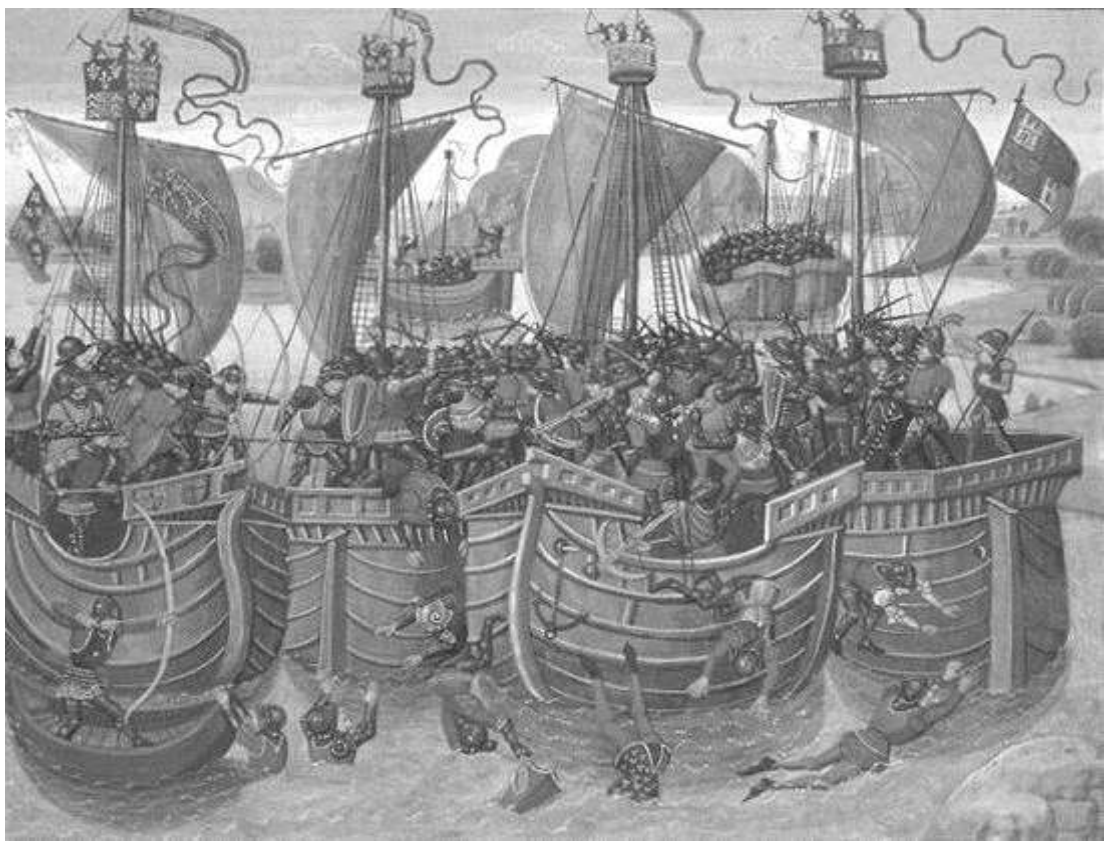

Figure 8: Medieval warships used as a floating battle field. The French fighting the English at the naval Battle of Guernsey (1342). (Bibliotheque Nationale de France FR 2643) 

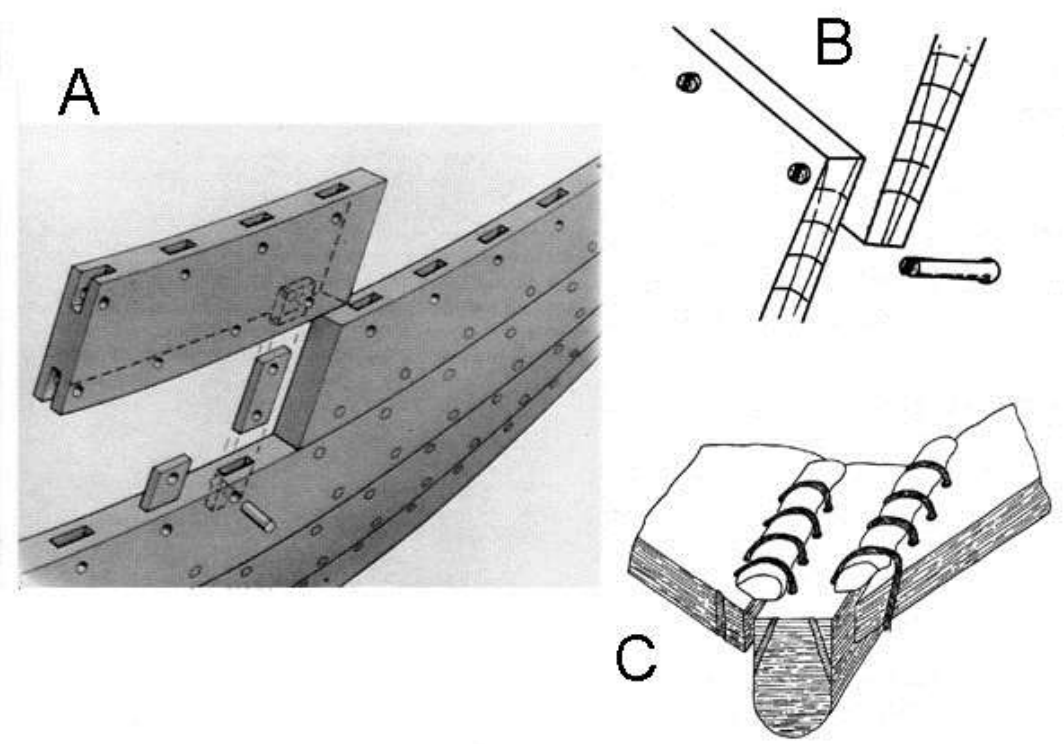

Figure 9:

Different techniques of plank fastening prevailing in certain regions. A: The mortise and tenon joints in the Mediterranean. B: The Clinker technique with overlapping strakes in northern Europe. C: Lashing planks using plant fibres in Arabia. (Courtesy of CMA - University of Southampton).

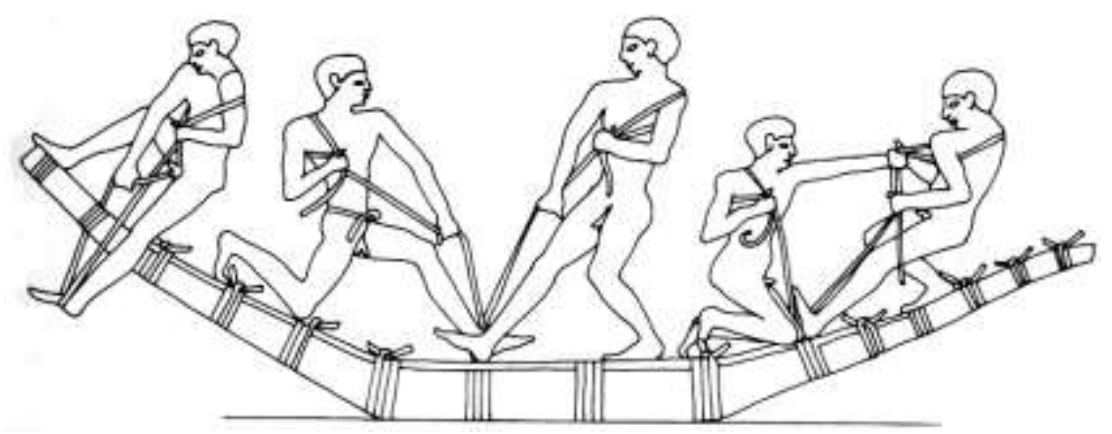

Figure 10: Making a papyrus raft using the lashing technique. From the Mastaba of Achethetep at Saqqara - Fifth-Dynasty. (After Hodges 1992: 93) 


\section{دراسات في آثار الوطن العربي 9}

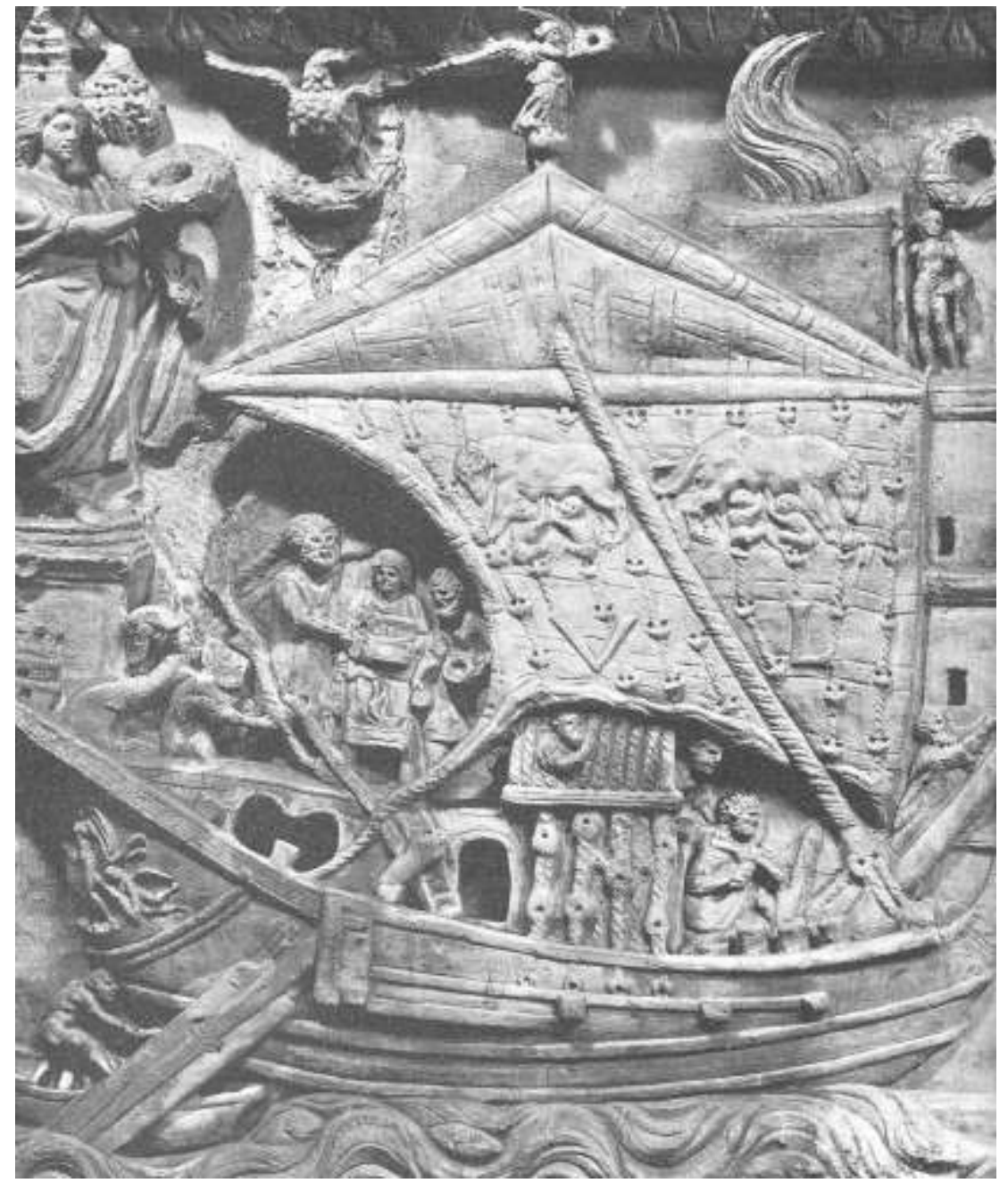

Figure 11. Rituals being carried out at the stern of a merchant ship where an altar was placed. (After Casson 1996: 112). 


\section{دراسات في آثار الوطن العربي 9}

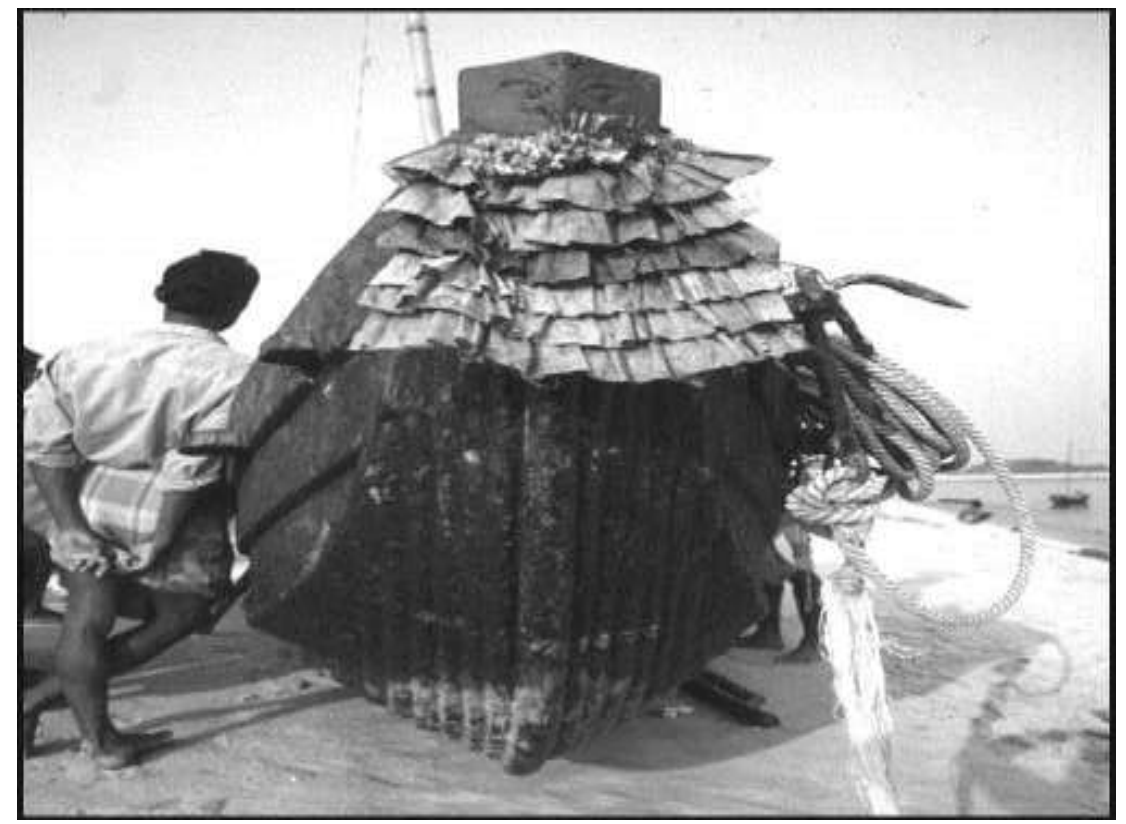

Figure 12: The carving of the goddess Kali on the bow of an Indian fishing boat (Courtesy of Dr. L. Blue).

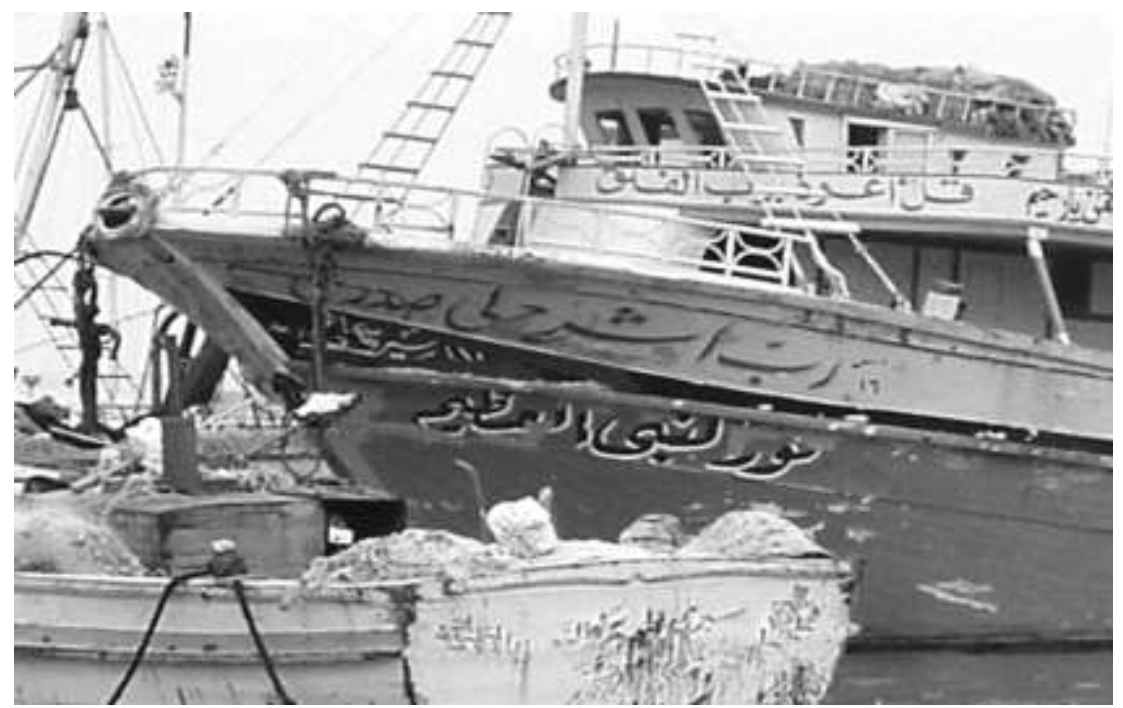

Figure 13: Many boats in our society carry religious phrases or symbols to protect the boat and its crew. This is considered a continuation of the symbolic value boats acquired through time. A fishing boat in the Eastern Harbour of Alexandria. (Photo by Saad Ahmad) 